\title{
Sustainability of the productive cash waqf institutions in Indonesia from an N-Helix perspective
}

\author{
D. Siswantoro \\ Department of Accounting, Faculty of Economics and Business, Universitas Indonesia, Depok, Indonesia
}

H. Rosdiana

Department of Public Administration, Faculty of Administrative Sciences, Universitas Indonesia, Depok, Indonesia

H. Fathurahman

Department of Business Administration, Faculty of Administrative Sciences, Universitas Indonesia, Depok, Indonesia

\begin{abstract}
The aim of this research is to identify the supporting factors for the sustainable development of productive cash waqf institutions in Indonesia. Currently, cash waqf in Indonesia is still mainly in the social sector, such as mosque development and social hospitals. Therefore, productive cash waqf must be developed further, especially for the supporting factors. The research method used is based on a qualitative case study with four productive cash waqf institutions. Some supporting factors are identified using main nodes in each aspect. The result shows that each aspect has an important issue, such as education (need early education on waqf), economics (supporting system to pay waqf), media culture (habitual activity to pay waqf), environment (not so familiar) and politics (supporting regulations and promotion). The additional helix is the belief of Muslims to participate in waqf which is the main factors.
\end{abstract}

\section{INTRODUCTION}

Act No. 41/2004 on waqf has been issued in Indonesia, and so far 82 cash waqf institutions have been registered by Badan Wakaf Indonesia (BWI) - Indonesian Waqf Board as legal government authorities in Indonesia. However, the total fund collection before September 2014 was still about 200 billion IDR (Republika, 2014). This fund is still far from the minimum amount of fund management needed in order to achieve the economics of scale. The institutions may only use the income generated from the waqf fund (the maximum allocation is $10 \%$ from income) if it is fully invested (according to BWI regulation No. 1/2009). Therefore, the sustainability of cash waqf will be a problem if the total cash management is still small.

Therefore, the sustainability of the cash waqf institutions is also an important issue. The cash waqf institutions will become more sustainable if they have the minimum amount of cash fund management that can generate sufficient income for their operating expenses. To analyse some supporting factors for the sustainability of cash waqf institutions, this report uses the N-Helix analysis. Previously, it started from a triple helix that used three aspects, such as education, economy and politics. The quadruple helix uses education, economy, politics and media culture. The quintuple helix adds environment as the fifth helix (Carayannis \& Campbell, 2011; Carayannis et al., 2012; Carayannis \& Rakhmatullin, 2014). Waqf is a social fund that must be maintained and organised in order to allocate income to recipients in need. In this case, it is appropriate to use the quintuple helix approach to analyse the sustainability of the cash waqf institutions.

Siswantoro and Rosdiana (2016) identified in previous research that cash waqf should be productive in terms of current or fixed asset types. Knowledge in creation and innovation is 
needed in this area to create sustainability. In fact, this is still based on conceptual and theoretical analysis. However, the main issue of cash waqf is actually that of having sufficient funds of cash waqf in order to productively generate income for operational and social activities.

\section{LITERATURE REVIEW}

To be sustainable, a cash waqf institution needs the minimum amount of capital necessary to achieve an economic scale that can generate enough income to cover operational expenses and targeted allocations for needy. For one cash waqf institution, the minimum amount of capital to be covered is 50 billion IDR. For example, operating costs per year are 400 million IDR. An institution can only take a 10\% fee from investment income, so they must generate a minimum income of four billion per year. If the expected return is $8 \%$, the minimum total investment is 50 billion IDR.

Furthermore, Nasution (2005) created a simulation with ten billion Muslims who give 5,000 to 100,000 IDR per month. The total amount of funds collected is three trillion IDR. In fact, the total amount of funds received in more than five years was only 200 billion IDR. The waqf fundraising programme is also not big enough in other countries, such as Bangladesh. In 2013 they only collected 436,010,591 Taka (52 billion IDR) through Islami Bank Bangladesh Limited (IBBL), while Social Investment Bank Limited SIBL raised 84,577,685 Taka (ten billion IDR). In 2012, Perbadanan Wakaf Selangor in Malaysia, where waqf payments can count as a taxable income deduction, collected 126 billion IDR in one year. In Singapore, they use sukuk (Islamic obligation) to raise waqf funds. In one issuance they can collect almost 400 billion IDR. In 2015, the total amount of waqf assets in Singapore was almost 6.5 trillion IDR, which generates an income of 111 billion IDR per year. Only 22.5 billion IDR is allocated to the needy and the social sector. The rest is reinvested in the waqf fund. From this evidence, we can see how waqf funds should be managed and developed in Indonesia. Bigger waqf funds will better sustain the cash waqf institutions.

To analyse the sustainability of cash waqf institutions in Indonesia, the quintuple helix approach can be used to evaluate the institutions from the aspects of education, economy, media culture, environment and politics. Carayannis et al. (2012) analysed the cycle of the quintuple helix in sequence from those five aspects. If each aspect can strengthen the sustainability of the others, it will create an innovation that will lead to sustainable development. Siswantoro and Rosdiana (2016) found that the important aspects in the sustainability of cash waqf development are educational, economic and political systems. In fact, Indonesia still suffers from the existence of cash waqf institutions, so not many people see this as a new issue.

Additional helix may be possible, since each issue has specific characteristics that may be different from previous studies. Carayannis and Campbell (2012) state that the development of technology can cause sustainable development. Leydesdorff (2012) emphasises the need for additional helix to prove the sustainability of specific issues and ease the analysis. Park (2014) explains that economic development can cause changes in factors to adapt for sustainability.

\section{RESEARCH METHODOLOGY}

The post positivist paradigm is used in this research along with the qualitative method. Research objects in this study were Badan Wakaf Indonesia (BWI), Tabung Wakaf Indonesia (TWI), Wakaf Center (Water) and Pusat Pengembangan Wakaf Daarut Tauhiid (DT). These four institutions have similar characteristics to the cash waqf, as they focus on productive assets.

Unit analysis was classified based on the research objective of six people who have custody of and manage the waqf institutions, government, and Islamic banks. Then, the data analysts applied the qualitative method, content analysis and narrative. The objective of analysis used content analysis by coding the interview transcript with the main theme. The helix aspect required each informant to determine the sustainable development aspect of the cash waqf institutions in Indonesia. 
The credibility of the research was achieved by checking other responses from the Directorate of Waqf, Ministry of Religious Affairs and observing research objects. The research may have strong transferability as the unit analysis was taken from qualified and competent resources (Lincoln \& Guba, 1985).

\section{ANALYSIS}

The analysis of the sustainable development of the cash waqf institutions was based on the quintuple helix approach. Additional helixes were added since one issue, such as the iman system or belief, may not fit in a particular helix (see Figure 1). Issues with the cash waqf are different from those of the fixed asset waqf, which requires large assets, such as land or buildings. In the cash waqf, Muslims can pay any amount of money, as there is no minimum amount. The important issue is whether Muslims believe in the cash waqf institution. If they do not believe in the institution, they will not pay the waqf. This could cause less sustainable development.

Society, especially Muslims, needs to be educated to create awareness of the waqf. Therefore, the first effort should be made by the education system. Once they are well educated, the economic system must improve so that Muslims can pay the cash waqf. This must also be supported by the payment system. In addition, Iman or belief in the cash waqf institution is also an important aspect, because a cash waqf donation does not have to be a large amount, a small amount is also possible, so paying the cash waqf is not a burden.

The media must support the cash waqf, and paying it should be part of a society's culture. If this phenomenon occurs, the cash waqf is likely to be sustainable. The media can also educate people to participate in this programme. The cash waqf can also be related to the environmental system if it is allocated to an environmental cash waqf programme. In Indonesia, the environment is an interesting issue that has the potential for further development, as Indonesia is covered with forests and farmland.

The political aspect also supports the sustainable development of the cash waqf institutions in Indonesia. The government should support the development of the cash waqf institutions by easing regulations and providing incentives to the institutions. The political aspect would affect the education aspect by increasing educational awareness and policies that support cash waqf development.

The analysis of the sustainable development for the cash waqf institutions in Indonesia is based on the sextuple helix as follows:

\subsection{Education system}

Socialisation is an important issue for this aspect, for example, giving practice and training on the cash waqf. Other issues that arise are supporting technology in education, research, sponsorship for waqf development, early childhood education, testament and incentives in education (see Figure 2).

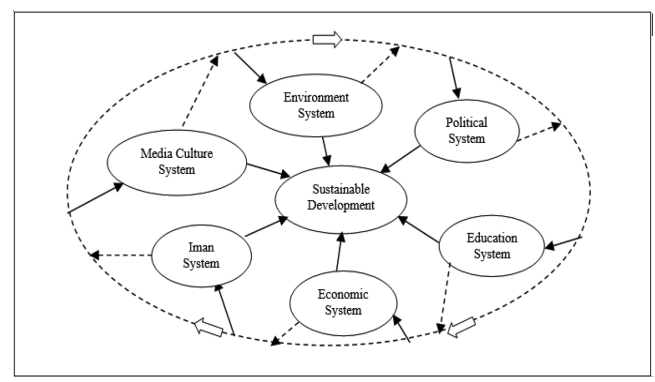

Figure 1. Cycle dimension of the sextuple helix.

Source: Data processed. 


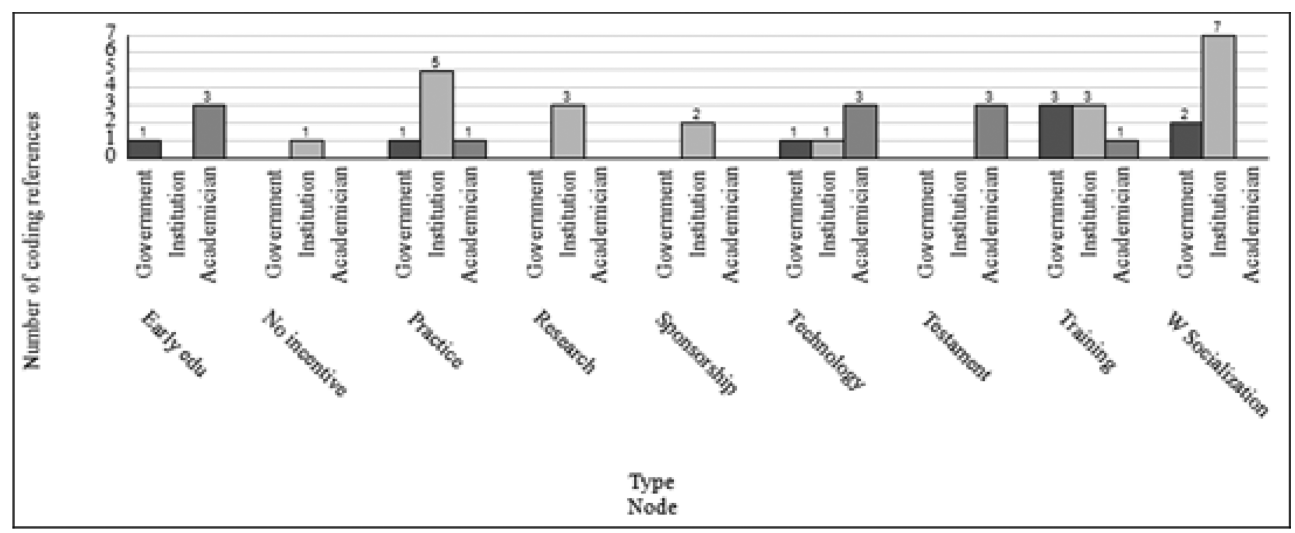

Figure 2. Education aspect of the cash waqf institution.

Source: Data processed.

The biggest issue in education for the waqf is that there has not been very much information dissemination, even though the Act was issued in 2004. This includes training and courses in schools and universities. The image of the cash waqf is not well known, so Muslims have not yet participated in the programme. Society needs to be aggressively educated and involved in marketing programme participation, like agency systems in insurance. Early childhood education should also be geared towards the cash waqf. This would help to create a strong image of the cash waqf for children before they become adults. Course programmes could be offered in senior high schools, since they may already be familiar with the cash waqf programme. In elementary schools, subject material on charity should be introduced to create awareness. The Islamic religion, of course, must focus on the practice of praying and having empathy for the poor and needy.

The cash waqf institutions must utilise technology that is capable of bringing socialisation to the cash waqf. Social media is a cheap and effective tool for marketing. Society needs to see the benefits of a productive waqf asset so that they will have a sense of belonging to this programme. In addition, sponsorship on waqf research and incentives by the government for further study can create triggers to develop the cash waqf.

\subsection{Economic system}

The economic aspect of the sustainable development of the cash waqf institutions in Indonesia allows society to participate in the cash waqf and makes it easy to pay for it. Important issues raised in this aspect are niche markets, trust, priority and unknowns from society. Other interesting issues are limited socialisation and the utilisation of a temporary cash waqf in banks (see Figure 3).

Understanding of the cash waqf becomes an interesting issue. Many people are reluctant to pay the waqf. In fact, it has a specific niche market, but not many people feel comfortable with all of the cash waqf institutions. People have a tendency to use specific institutions that they know well. Trust can also be an important issue for donors. Trust can be built if the institution is transparent and reliable. Society must know that the cash waqf institutions are reliable and meaningful, and that they are also of benefit to them.

A temporary deposit for the cash waqf can be an effective tool for boosting waqf income. The cash waqf institutions should co-operate with Islamic banks to promote this plan, so that they do not feel threatened. Another important issue is that society must know the real physical assets of the cash waqf, for example, hotels, rental houses, shops and office buildings. The poor and needy can also rent the store to sell their products. In other words, this will empower those to improve their life. This is a good example whereby the cash waqf can empower the poor and needy, as the generated income is also beneficial to them. Muslims would have strong incentives to participate in the cash waqf programme if they could see this process and its result. 


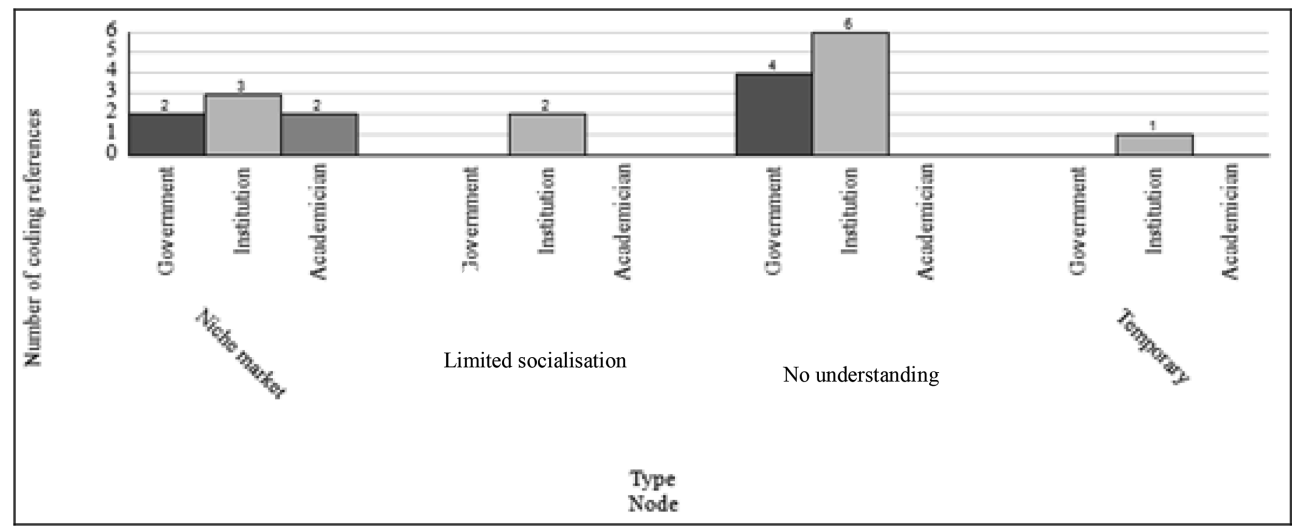

Figure 3. Economic aspect of the cash waqf institution. Source: Data processed.

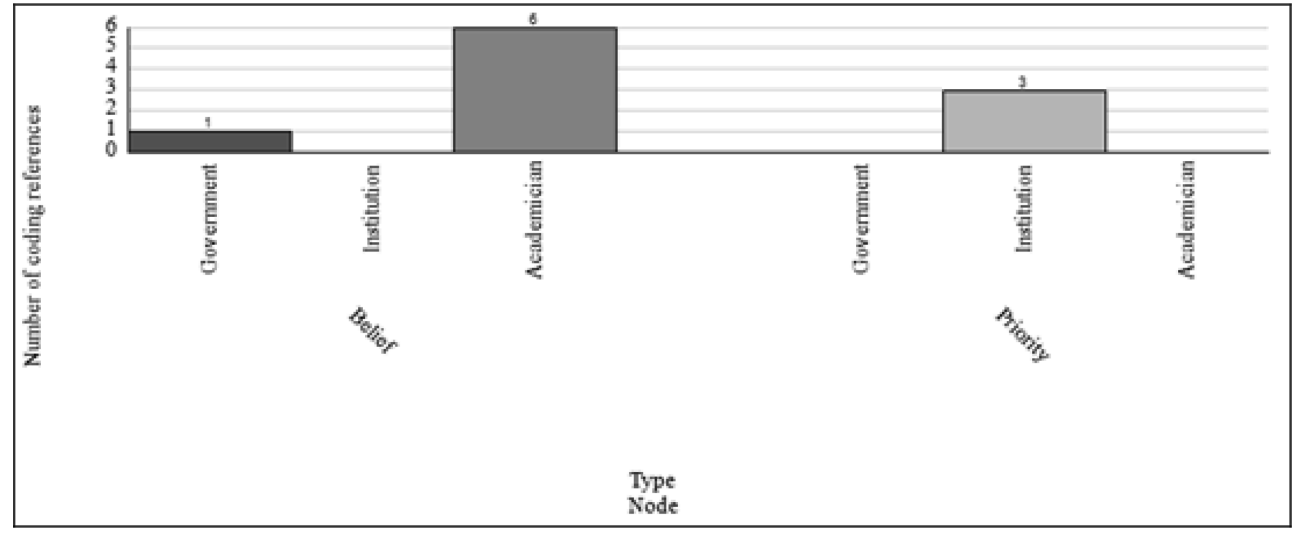

Figure 4. Iman aspect of the cash waqf institution. Source: Data processed.

\subsection{Iman system}

The waqf is not obligatory for all Muslims. Only those who have strong beliefs will participate in the cash waqf programme. It is necessary that the cash waqf programme be of a larger amount in order to generate a larger income and so increase the economic scale. Even if the participant only gives a small amount to the cash waqf, the total amount will be large and able to generate greater income if it is collected effectively. Therefore, the problem with the cash waqf is not the amount of money or its capability, but the willingness to pay. This stems from the belief or Iman of Muslims, as it is not an obligation, not many Muslims participate in the waqf (see Figure 4).

People are not familiar with the cash waqf as there are other types of charity, such as infaq (donation), shadaqah (charity) or zakat (tithe). In fact, the cash waqf is like waqf in general, but it focuses on productive assets. The cash waqf has lifetime benefits for wakif (people who pay the cash waqf). It does not require large amounts to be paid, but the collective total will be large. 


\subsection{Media culture system}

Media has quite a significant role in the sustainability of waqf development. Currently, media is not only based on common media, such as television, radio and newspapers, but on social media, based on the Internet. Some cash waqf institutions have utilised the media, such as radio and television, to promote their programmes. In addition, they have also used social media, such as Facebook, Twitter and YouTube. If the institution promotes the cash waqf aggressively, this can be beneficial to the marketing of the cash waqf. Media promotion also needs a good example of cash waqf practices; therefore, a professional cash waqf institution is needed (see Figure 5).

Developing supporting systems to ease the process of waqf payments can create a culture that supports the sustainable development of the cash waqf institutions. This can be in the form of automatic payment schedule of waqf. The Islamic banks must also support the cash waqf programme by promoting it to their customers. Culture can be shaped if it becomes a habit in society. The government should also give incentives and support to make it easier for people to give cash waqf systematically. The cash waqf can be in the form of productive fixed assets that generate income (productive assets).

\subsection{Environment system}

This aspect is suitable in an Indonesian context. Feasible programmes, such as plantation waqf or agriculture waqf, should support it. Agriculture waqf can be in the form of profit sharing with the farmer who cultivates the land. This would benefit to farmers (see Figure 6).

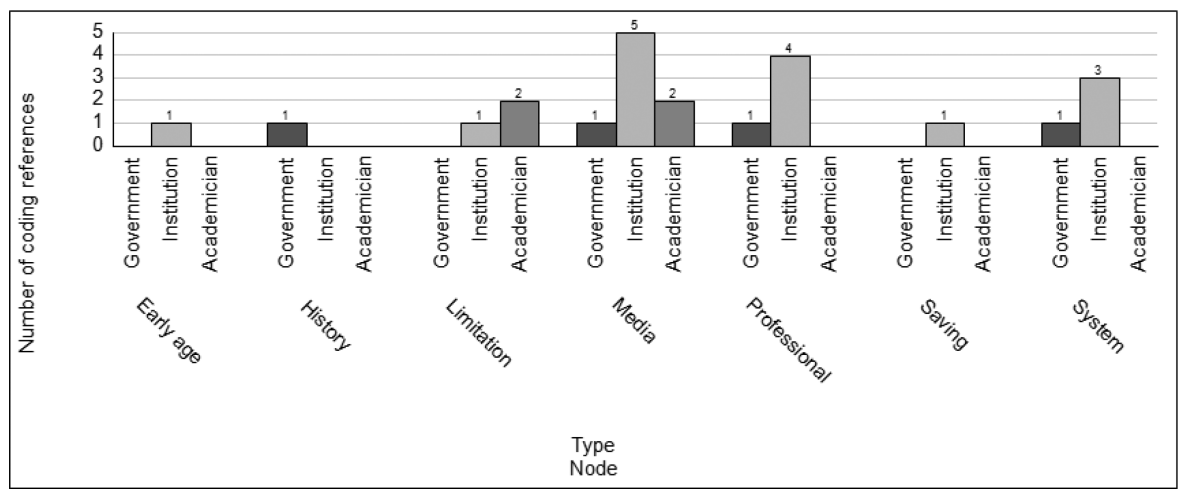

Figure 5. Media \& culture aspect of the cash waqf institution. Source: Data processed.

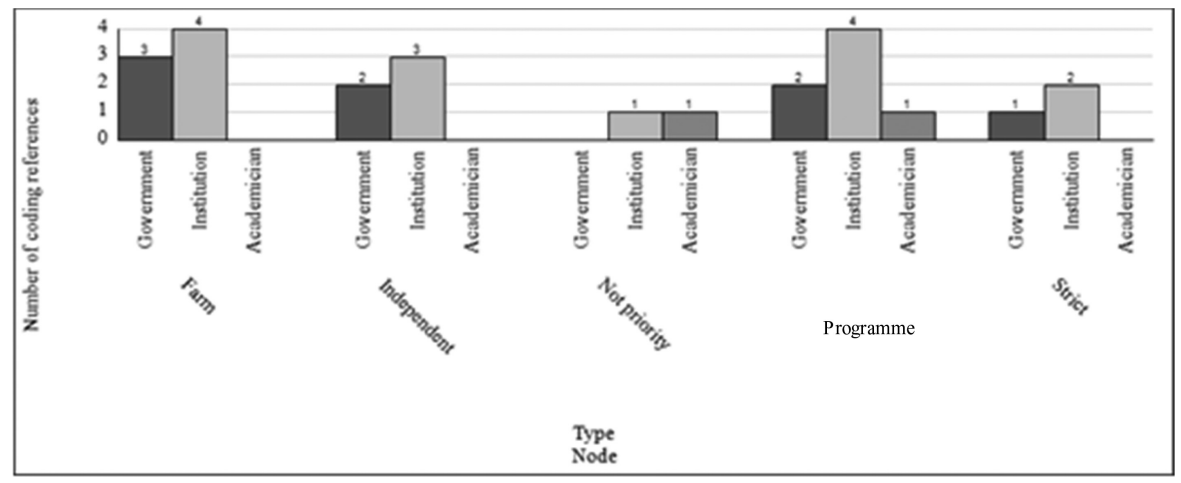

Figure 6. Environment aspect of the cash waqf institutions.

Source: Data processed. 


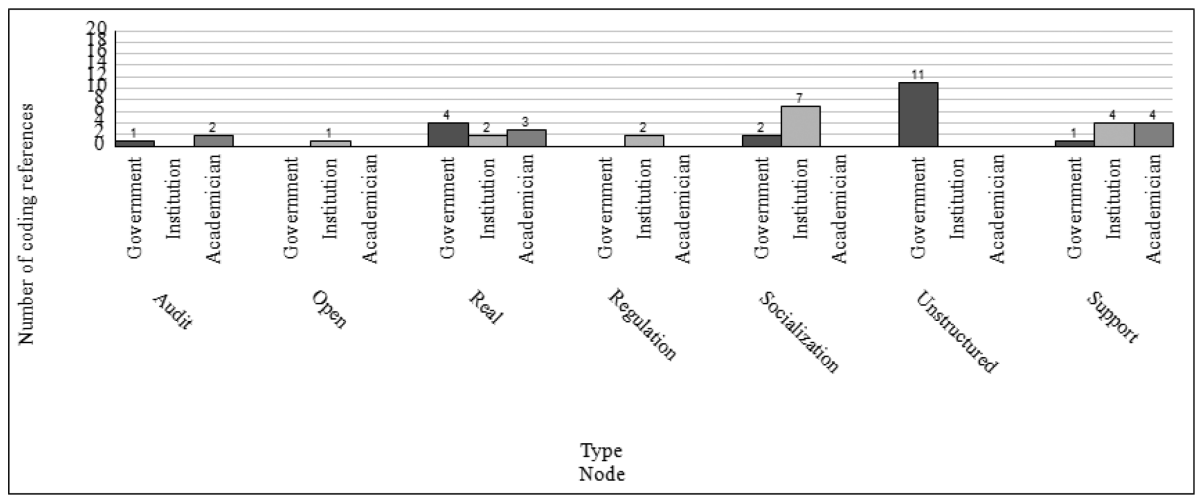

Figure 7. Political aspect of the cash waqf institution.

Source: Data processed.

Waqf in this area can help to preserve the environment and protect the earth from further damage. The cash waqf can also be allocated to a natural electricity power supply. This can benefit institutions by saving energy, which means that the cash waqf supports the environment. The impact may be indirect, but the benefits are long term. Nevertheless, this programme is still not likely to be seen as a top priority by society, as the effect is not direct and it takes a long time to see the results. However, this may affect the life and sustainability of human beings.

\subsection{Political system}

The political system in Indonesia may also be able to support the sustainable development of the cash waqf institutions. Indonesia is a developing country that still requires alignment from the government. Issues that occur in this aspect are unstructured waqf mechanisms, lack of government socialisation, good practice and support from others. BWI and the Ministry of Religious Affairs should have clear job descriptions for reporting, including the monitoring and control of the cash waqf institutions. The report must be disclosed to the public by an online system so that the performance of the cash waqf institution can be easily accessed (see Figure 7).

The government should have promotion programmes for cash waqf, similar to those for taxation. There should be targets for each city, district and province. The amount of the cash waqf would be increased by region and time period. Currently, the government has prepared cash waqf information by publishing an e-book that can be downloaded on the website, but this has not been promoted to the public.

The problem with the socialisation of cash waqf is that there is no interesting cash waqf programme that the government can promote. A good pilot project is needed from a productive cash waqf programme that would encourage the public to participate in it. At this time, this only occurs in the private sector. However, corporations can ask to be involved in the cash waqf programme by offering programmes from Corporate Social Responsibility (CSR). Companies would benefit from this, as they will gain a positive image in society.

\section{CONCLUSION}

The sustainable development of the cash waqf institutions can be seen from the N-Helix perspective, based on the quintuple helix. From this, we can see which aspects are important and what institutions need to be concerned about. This covers education, economics, media culture, the environment and political systems. For additional consideration, a sixth helix is added, which is the Iman system or belief of the benefits of cash waqf. The cash waqf can be paid in small amounts so that any Muslim can join, as long as they have these beliefs. 
This research may add to the study of Siswantoro and Rosdiana (2016), which is still at the preliminary stage at this time.

\section{REFERENCES}

Badan Wakaf Indonesia. (2009). Regulation of Badan Wakaf Indonesia No. 1/2009 on Pedoman Pengelolaan dan Pengembangan Harta Benda Wakaf Bergerak Berupa Uang (Guide to management and development of moveable cash waqf).

Carayannis, E.G. \& Campbell, D.F.J. (2011). Open innovation diplomacy and the 21st century fractal research, education and innovation (FREIE) ecosystem: Building on the quadruple and quintuple helix innovation concepts and the "Mode 3" knowledge production system. Journal of Knowledge Economics, 2, 327-372.

Carayannis, E.G. \& Campbell, D.F.J. (2012). Mode 3 knowledge production in quadruple helix innovation systems. New York: Springer.

Carayannis, E.G., Barth, T.D. \& Campbell, D.F.J. (2012). The quintuple helix innovation model: Global warming as a challenge and driver for innovation. Journal of Innovation and Entrepreneurship, 1(1), 2. doi:10.1186/2192-5372-1-2.

Carayannis, E.G. \& Rakhmatullin, R. (2014). The quadruple/quintuple innovation helixes and smart specialisation strategies for sustainable and inclusive growth in Europe and beyond. Journal of the Knowledge Economy, 5(2), 212-39. doi:10.1007/s13132-014-0185-8.

Leydesdorff, L. (2012). The triple helix, quadruple helix, ..., and an N-tuple of helices: Explanatory models for analyzing the knowledge-based economy? Journal of the Knowledge Economy, 3(1), 25-35. doi:10.1007/s13132-011-0049-4.

Lincoln, Y.S. \& Guba, E. (1985). Naturalistic inquiry. California: Sage Publications.

Nasution, M.E. (2005). Wakaf tunai dan sektor volunteer. In M.E. Nasution \& U. Hasanah (Eds.), Wakaf tunai inovasi financial Islam peluang dan tantangan dalam mewujudkan kesejahteraan umat (pp. 28-50). Jakarta: Pusat Kajian Timur Tengah dan Islam, Universitas Indonesia.

Park, H.W. (2014). Transition from the triple helix to N-tuple helices? An interview with Elias G. Carayannis and David F.J. Campbell. Scientometrics. doi:10.1007/s11192-013-1124-3.

Republika. (2014). Dana Wakaf Capai $R p 200$ Miliar. http://www.republika.co.id/berita/koran/ khazanah-koran/14/09/18/nc2z881-dana-wakaf-capai-rp-200-miliar.

Siswantoro, D. \& Rosdiana, H. (2016). Sustainability of cash waqf development in Indonesia: A quintuple helix perspective. Sains Humanika, 8(1-2), 111-116. 